\title{
Fatigue Life Assessment of Weld Surfacing of LB-52 Solid Wire on SCM 440 Alloys Steel Propeller Shafts
}

\author{
Siva Sitthipong, Prawit Towatana, and Amnuay Sitticharoenchai
}

\begin{abstract}
The damage to the propeller shaft, a principal mechanical component in the power transmission system of the Kolek Boats makes engines work harder than normal attributed to less transmission efficiency. Operating boats with the damaged propeller shaft increases the rate of fuel consumption per distance and cost of fishing which affects income of coastal fishermen. The result of a preliminary survey of Cut-Stern Kolek Boats at Kaoseng Community revealed that the service life of the damaged propeller shafts caused by the fatigue failure would be repaired by shield metal arc welding process. The statistical analysis showed that the useful life depended on fatigue endurance limit of welding surface. When they were back to be used again. The objective of this research was to study the fatigue life of hardfacing surface LB-52 solid wire. The method of this research included )a) building up the hardfacing surface (b) forming specimen from hardfacing surface and (c) finding out the fatigue life by fatigue testing machine base on ASTM E739-91 standard. The results of this research indicated that hardfacing surface LB-52 could not receive fatigue stress exceed $500 \mathrm{MPa}$. The propeller shafts after being repaired will have very short service life, which is not feasible in engineering economy.
\end{abstract}

Index Terms_-Propeller shaft, hardfacing surface, solid wire fishing boats.

\section{INTRODUCTION}

The popular southern local fishing boats are the Kolek boats which are modified by the presence of engines and long tail shaft at the cut-stern. A traditional Kolek boat then becomes a cut-stern Kolek boat, as shown in Fig. 1.

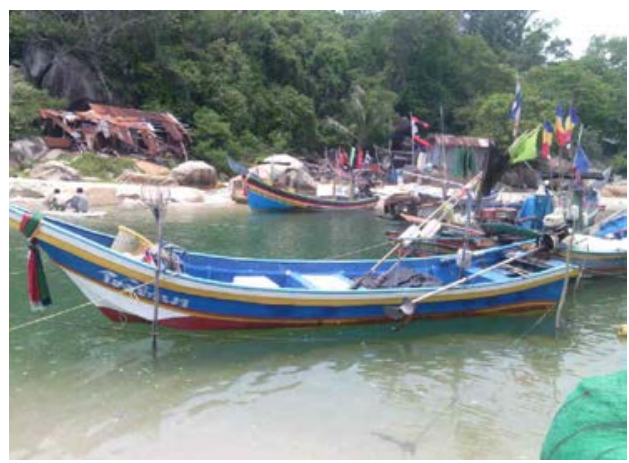

Fig. 1. The cut-stern kolek boats.

There are several reasons why the Cut-Stern Kolek boat

Manuscript received January 22, 2017; revised March 1, 2017.

Siva Sitthipong, Prawit Towatana and Amnuay Sitticharoenchai are with Marine and Coastal Resource Institute, Prince of Songkla University, Thailand respectively. (e-mail:mechmat.s@gmail.com, prawit.t@psu.ac.th, Sittiben@psu.ac.th). are more popular than the traditional Kolek boats. The cost of building tradition Kolek boats are 2 times higher than the cutstern one. For the second reason, it has the abilities to maintain good balance and mobility against winds and waves. Its shallow hull prevents itself from tipping over. Lastly, its smaller size and lighter weight require lesser driving force and fuel. Only 2-3 people are needed to operate the boat for fishing. From these reasons, the cut-stern Kolek boats are popular among the fishermen, while the traditional Kolek are just the past generation models which were continuously used and deteriorated with times [1], [2].

The cut-stern Kolek were driven by using driving forces from engines. The propeller shaft, as shown in Fig. 2, was the part of main machine in the transmission system of the cut-stern Kolek [3]. While the boat is being used, the shaft works all the time. The shaft receives cyclic loads continuously, which it has a high statistical damaged rate from fatigue mechanism. Welding resurfacing by using shielded metal arc welding process is the current welding repair technique [4], [10]. Some propeller shafts can only be used shortly, while others may last for a long time, since the fatigue life was limited by the weld metals' hardness from the information and reason above, this research aims to investigate the fatigue life of hardfacing surface of LB-52 propeller shafts.

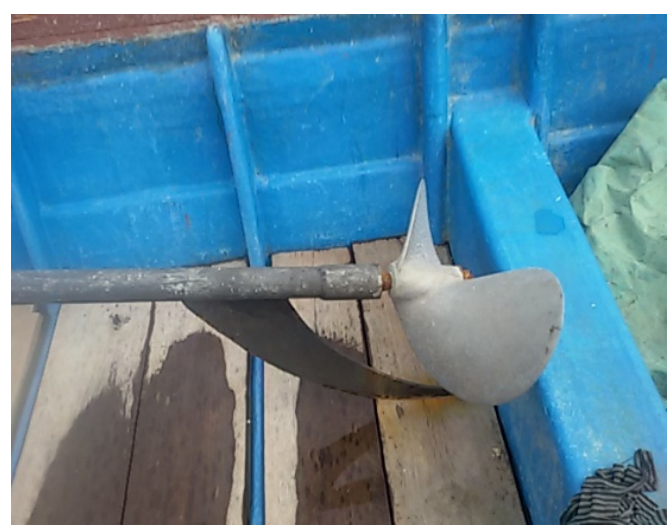

Fig. 2. Propeller shafts.

\section{Materials AND EXPERIMENTAL PROCEDURE}

\section{A. Creating the LB-52 Hardfacing Surface}

The SCM 440 alloy steels were formed as c-shape with 3 inches cross-sectional area. The chemical compositions and mechanical properties of SCM 440 alloy steels are shown in Table I and II. After that, the specimens were cut into 18 pieces. Each specimen has a length of $30 \mathrm{~cm}$. Then, the inner surface of c-shape channel was hardfaced by using shielded metal arc welding, as shown in Fig. 3, with 4mm LB-52 
coated electrodes. The height of hardfacing surface is $20 \mathrm{~mm}$, as shown in Fig. 4. The beads were deposited in zigzag patterns. Electrodes were baked at $350^{\circ} \mathrm{C}$ for half hour, but there is no preheat and post weld heat treatment. The chemical compositions of welding electrodes are shown on Table Ш. LB-52 is a basic coated low hydrogen electrode suitable for welding heavy structures, high tensile strength jobs where impact strength at sub-zero temperatures are required. The basic coated formulation ensures a defect-free radiographic quality weld. The superb and well established flux formulation ensure excellent performance of the electrode in AC/DC $(+)$ in all welding positions except vertical down.

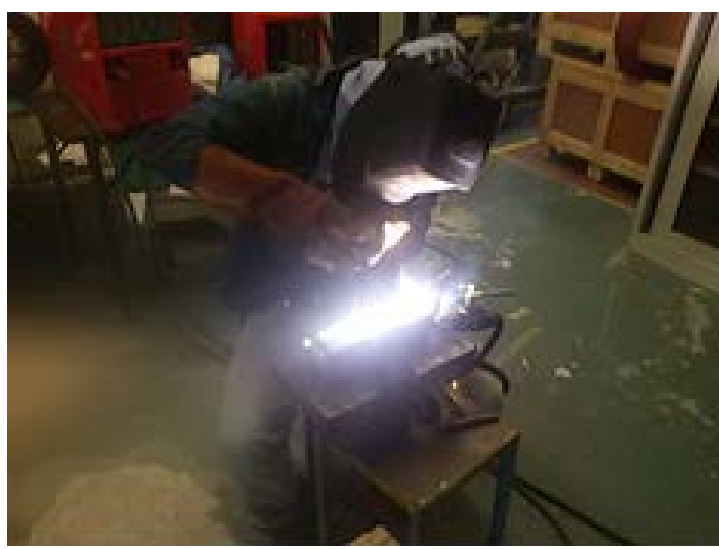

Fig. 3. Shielded metal arc welding.

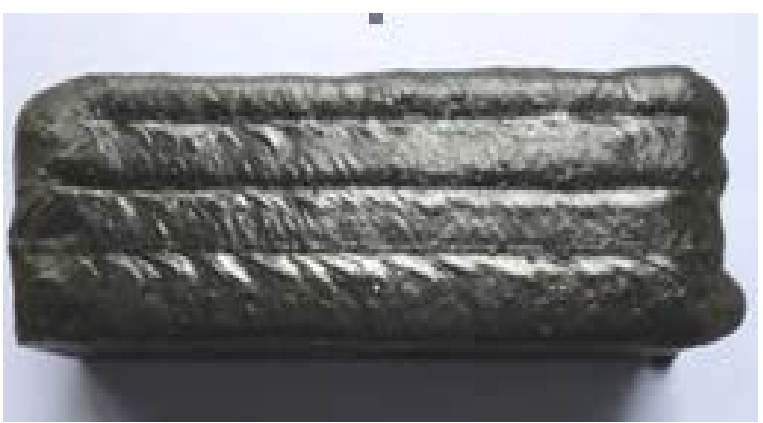

Fig. 4. Hardfacing surface.

LB-52 is suitable for all sorts of joining, repairing and fabrication of structural works which are suitable for medium and high tensile steels of grade $550 \mathrm{~N} / \mathrm{mm}^{2}$., The applications include; welding of structures, highly restrained joints, bridges, railway coaches \& wagons, plants, ships, tugs, barges, trawlers, dredgers, storage tanks, boilers, pipelines, grills etc., The electrode can be used as a non-machinable electrode on castings. Welding current condition is shown on Table IV. The controlled parameters for welding, using the coated electrodes, are illustrated in Table V, and Table VI shows the mechanical properties of LB-52 solid wire.

\begin{tabular}{|c|c|}
\hline Element & Content (\%wt) \\
\hline $\mathrm{C}$ & $0.38-0.43$ \\
\hline $\mathrm{Si}$ & $0.15-0.35$ \\
\hline $\mathrm{Mn}$ & $0.60-0.85$ \\
\hline $\mathrm{P}$ & Max.0.03 \\
\hline $\mathrm{S}$ & Max.0.03 \\
\hline $\mathrm{Cr}$ & 0.9-1.2 \\
\hline Mo & $0.15-0.30$ \\
\hline $\mathrm{Ni}$ & Max.0.25 \\
\hline $\mathrm{Cu}$ & Max.0.30 \\
\hline
\end{tabular}

\begin{tabular}{ll} 
TABLE П: MECHANICAL PROPERTIES OF SCM 440 \\
\hline Tensile Strength & $>980 \mathrm{MPa}$ \\
Yield Strength & $>830 \mathrm{MPa}$ \\
Brinell Hardness & $285-352 \mathrm{HB}$ \\
Percentage of elongation & $>12 \%$ \\
Percentage of area reduction & $>45 \%$ \\
Impact value (charpy test) & $>59 \mathrm{~J} / \mathrm{cm}^{2}$
\end{tabular}

TABLE Ш: CHEMICAL COMPOSITION OF LB52 SOLID WIRE

\begin{tabular}{cc}
\hline Element & Content (\%wt) \\
\hline $\mathrm{C}$ & 0.08 \\
$\mathrm{Si}$ & 0.6 \\
$\mathrm{Mn}$ & 0.94 \\
$\mathrm{P}$ & 0.011 \\
$\mathrm{~S}$ & 0.006 \\
\hline
\end{tabular}

TABLE IV: WELDING CURRENT CONDITION

\begin{tabular}{cc}
\hline Size & Current \\
\hline $2.5 \times 350 \mathrm{~mm}$ & $70-100 \mathrm{~A}$ \\
$3.15 \times 150 \mathrm{~mm}$ & $90-140 \mathrm{~A}$ \\
$4.00 \times 450 \mathrm{~mm}$ & $140-200$ \\
& A \\
$5.00 \times 450 \mathrm{~mm}$ & $190-250$ \\
& A \\
\hline
\end{tabular}

\begin{tabular}{ll} 
TABLE V: WELDING PARAMETERS \\
\hline Types of electrode & LB-52 \\
Diameter of wires & $4.0 \mathrm{~mm}$ \\
Welding current & $140 \mathrm{~A}$ \\
Welding voltage & $24.5 \mathrm{~V}$ \\
Welding speed & $150 \mathrm{~mm} / \mathrm{min}$ \\
Heat Input & $1.37 \mathrm{KJ} / \mathrm{mm}$ \\
\hline
\end{tabular}

TABLE VI: MECHANICAL PROPERTIES OF LB-52 SOLID WIRE

$\begin{array}{lr}\text { Tensile Strength } & 540 \mathrm{~N} / \mathrm{mm}^{2} \\ \text { Yield Strength } & 460 \mathrm{~N} / \mathrm{mm}^{2}\end{array}$

Percentage of elongation

Percentage of area reduction $26 \%$

Impact value

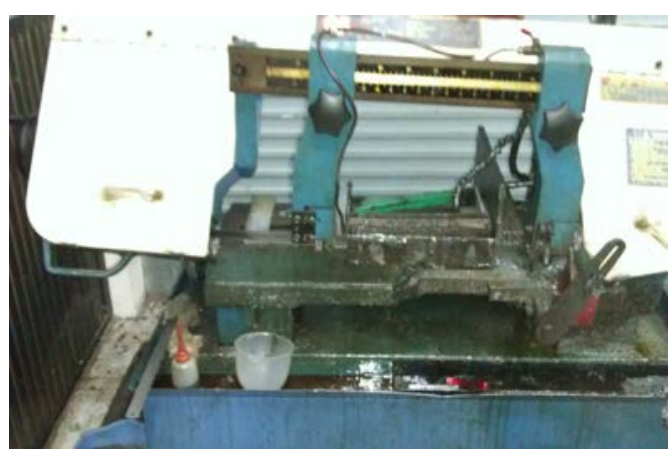

Fig. 5. Cutting with square-band saw.

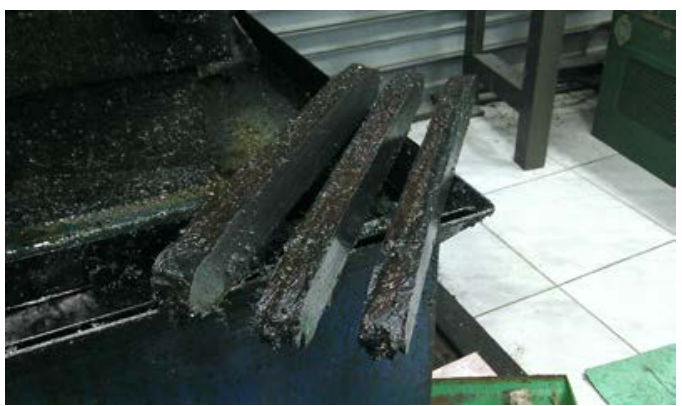

Fig. 6. Specimen after cutting. 


\section{B. Forming the Specimens from LB-52 Hardfacing Surface That Had Been Created}

Twenty pieces of hardfacing surface of LB-52 were taken for cutting with $12.5 \mathrm{~mm}$ width $\times 226 \mathrm{~mm}$ length square-band saw, as shown in Fig. 5 and 6. Sixty pieces of specimens were obtained after cutting.

Then, face milling the specimens was conducted, as shown in Fig. 7. The specimens were lathed, as illustrated in Fig. 8, to obtain the diameter of $12.18 \mathrm{~mm}$ and length of $226 \mathrm{~mm}$. Both ends were dropped off shoulders at $1 \mathrm{~mm}$ with 45 degree angle. At $65 \mathrm{~mm}$ from both ends, the fillets of 30 degree angle were created, as shown in Fig. 9. Lastly, the specimens were polished to obtain the smooth and shiny surface before testing as shown in Fig. 10.

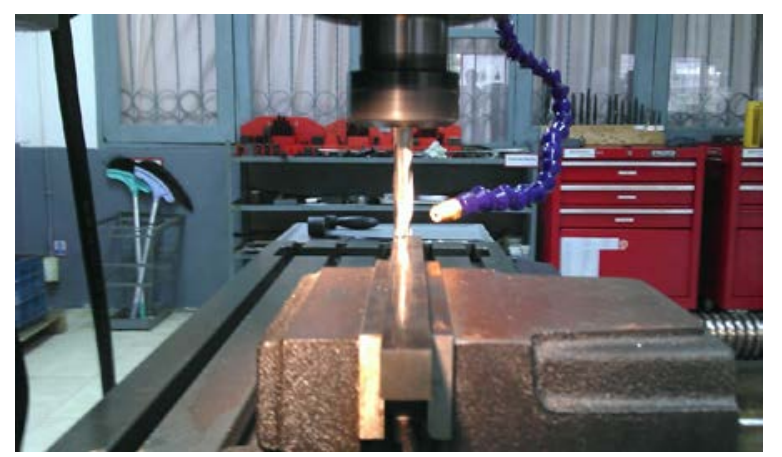

Fig. 7. Face milling the specimens.

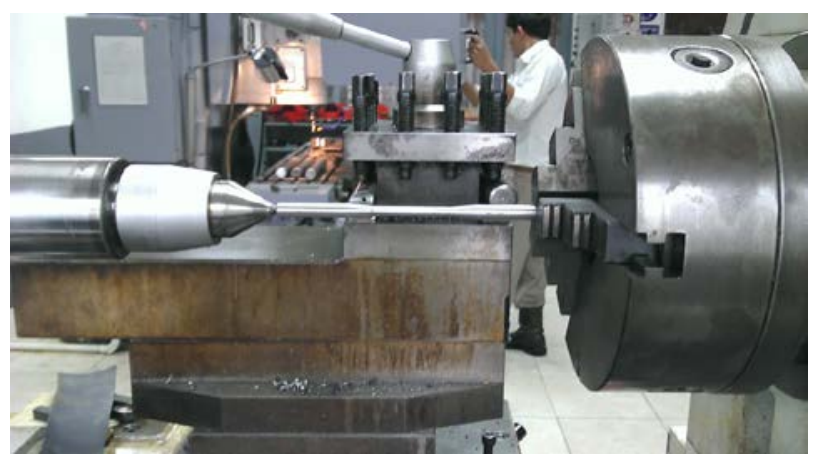

Fig. 8. Lathed the specimens.

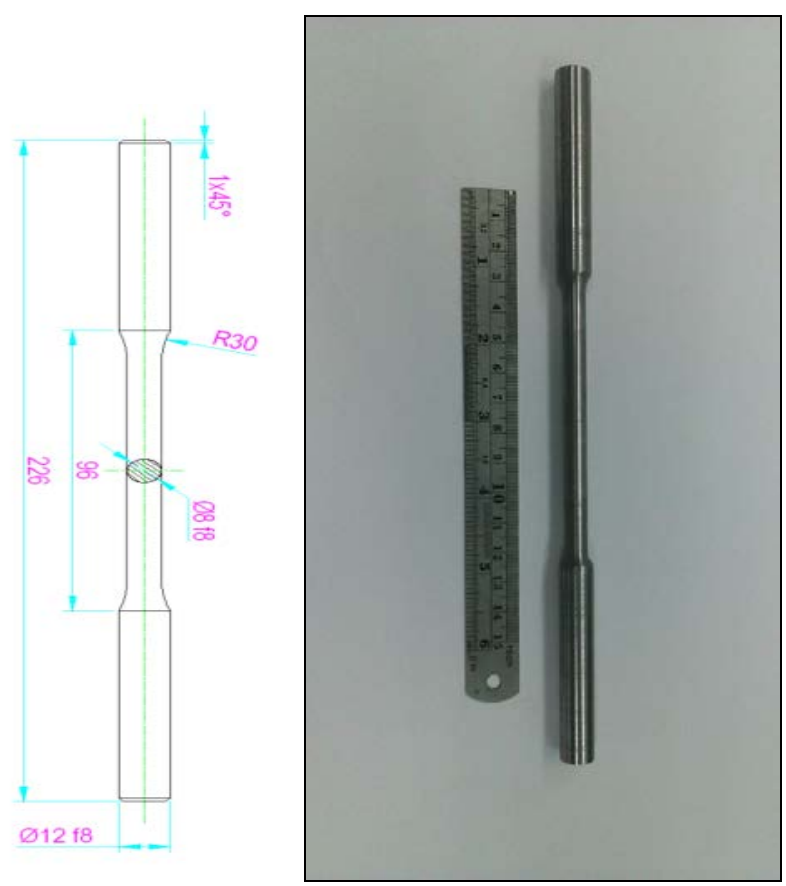

Fig. 9. Fatigue testing specimens.

\section{Testing the Fatigue Strength of Specimens Created from LB-52 Hardfacing Surface}

The research is highly reliable, since it follows the ASTM E739-91standards [11], [12]. Every single specimen was exposed to the x-ray beam to search for any defection feature. The example shown in Fig 11. The failed specimens were screen out.

All the 60 specimens from shielded metal arc welding with LB-52 coated electrodes were taken for fatigue strength test, using the rotating beam fatigue testing machine, as shown in Fig. 12. This test conforms to ASTM E739-91 standards. The loads for testing the fatigue strength were changed by 10 loads, each load was tested by 6 specimens. The cyclic torsional-flexural loadings were applied on the specimens until they broke apart.

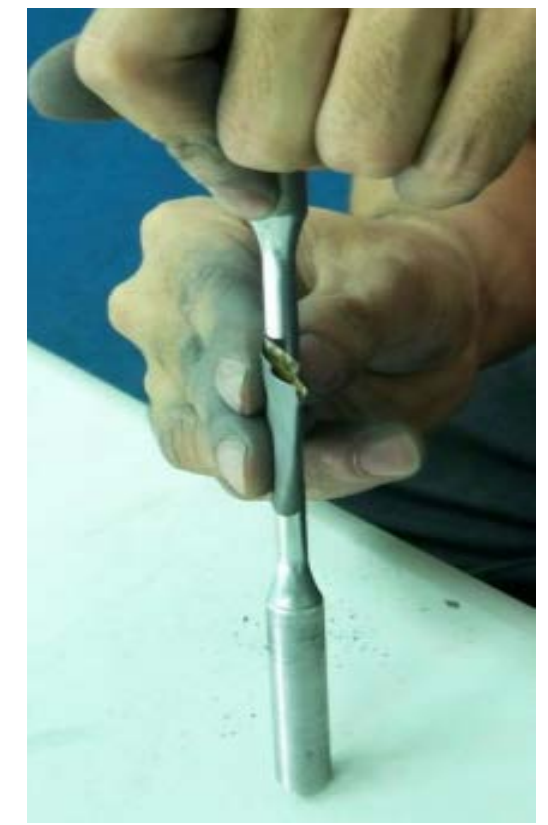

Fig. 10. Surface polishing.

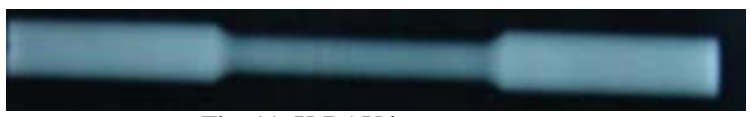

Fig. 11. X-RAY images.

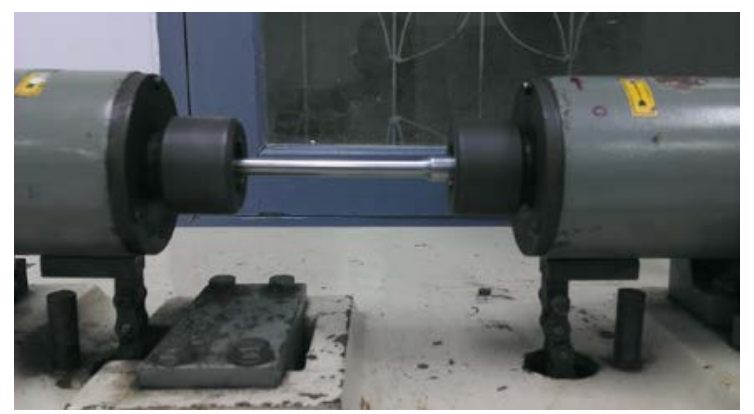

Fig. 12. Fatigue testing machine.

\section{RESUlTS AND DISCUSSION}

Stress and cycle recorded data that make specimens fracture on Table VII and display their relationship on the graph as shown in Fig 13. Each value of stress used 6 specimens for testing, as stated in the standard. Each specimen produced similar fatigue strength to the others, making the average values from each stress interval reliable. 
The use of LB-52 welding electrodes for hardfacing were proved to be ineffective for prolonging the service life propeller shafts. The research is highly reliable, since it follows the ASTM E739-91standards

TABLE VII: WELDING PARAMETERS

\begin{tabular}{cc}
\hline Stress for testing & Average cycle until fracture \\
\hline $150 \mathrm{MPa}$ & Not fracture \\
$200 \mathrm{MPa}$ & $1,026,310$ Cycle \\
$250 \mathrm{MPa}$ & 485,691 Cycle \\
$350 \mathrm{MPa}$ & 50,067 Cycle \\
$400 \mathrm{MPa}$ & 4,071 Cycle \\
$450 \mathrm{MPa}$ & 1,730 Cycle \\
$500 \mathrm{MPa}$ & Fractured at low cycle \\
$600 \mathrm{MPa}$ & Fractured at low cycle \\
$700 \mathrm{MPa}$ & Fractured at low cycle \\
$800 \mathrm{MPa}$ & Fractured at low cycle \\
\hline
\end{tabular}

Remarks: Stop the testing at 1,000,000 cycles for each specimen; the specimen that can receive loadings more than $1,000,000$ cycles will be reported as not fracture. In addition, the specimen that fracture before 1,000 cycles will be reported as fractured at low-cycle.

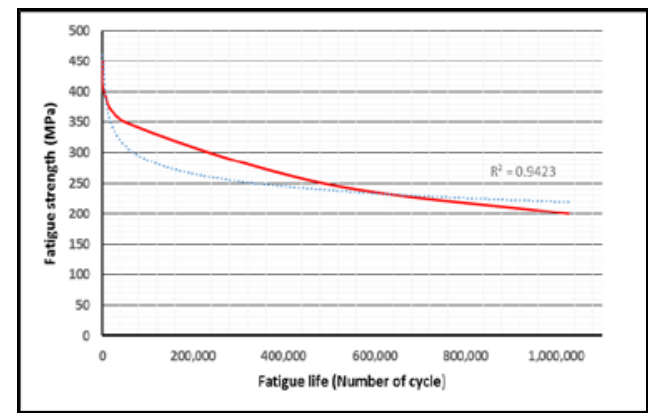

Fig. 13. S-N Curve of surface welding.

The analyzed cyclic stress $\left(\sigma_{R}\right)$ were applied in (1) to predict the lifetime $\left(N_{R}\right)$ of fatigue by using Basquin's power law [13]. The constants A and B are related to the experiment. By plotting the service lives against the applied cyclic stresses on shafts through (2).

$$
\begin{gathered}
\sigma_{R}=\mathrm{AN}_{R}^{B} \\
\mathrm{~N}_{R}=10^{\frac{1}{-0.116}\left(\log \sigma_{r}-\log 2.997\right)}
\end{gathered}
$$

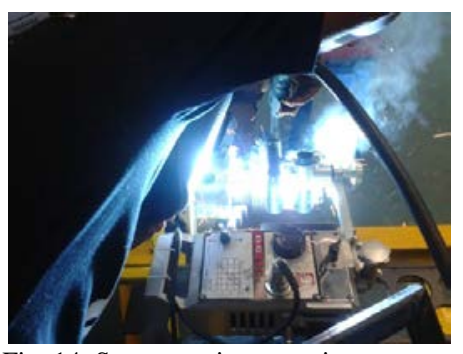

Fig. 14. Set up semi-automation process.

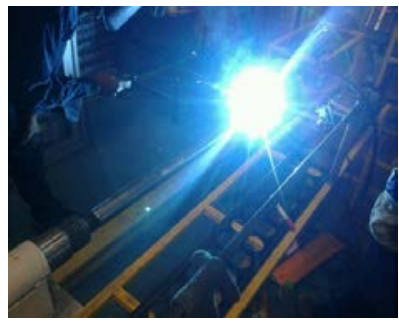

Fig. 15. Propeller shaft hardfacing.

\section{CONCLUSION AND RECOMMENDATION}

The LB-52 welding electrodes are inapplicable for welding repairs the propeller shafts of the cut-stern Kolek boats, since they hardfacing surfaces do not have enough strength to withstand the fatigue stresses that occurred on propeller shafts. The average fatigue stresses on propeller shafts of the cut-stern Kolek boats is $517 \mathrm{MPa}$. By using LB-52 welding electrodes for welding repairs, the propeller shafts after being repaired will have very short service life, which is not feasible in engineering economy. By baking welding electrodes before executing the shield metal arc welding, the welding process becomes easier. The quality of beads is also better. In addition, preheating and post weld heat treatment the specimens are recommended, in order to reduce the residual stresses within the specimens.

Propeller shaft design maintenance has to fulfill the operating requirements. The process of propeller shafts design maintenance consist of 4 stages: Concept Design Maintenance, Preliminary Design Maintenance, Contract Design Maintenance, and Detail Design Maintenance which are the iterative process according to the character of maintenance loop. All topics of propeller shaft design maintenance steps must be verified and defined in all the related design maintenance information. Service life, fatigue resistance and welding parameters are the importance topics that will be presented in this paper. The proving of propeller shaft design maintenance at the end is semi-automation hardfacing as shown in Fig.14 and 15 will be performed by sea trial.

\section{REFERENCES}

[1] S. Sitthipong, P. Towatana, A. Sitticharoenchai, and P. Bibithkosolvongse, "Improving the propeller shafts welding repair process of long tail boats," presented at the Thaksin University, Phatthalung, Thailand, August 27, 2015.

[2] S. Chainarong, S. Sitthipong and C. Meengam, "A study on influence of welding repair process parameters on long tail shafts," presented at the Thaksin University, Phatthalung, Thailand, August 27, 2015.

[3] S. Chainarong, S. Sitthipong and C. Meengam, "Influent of stress to mechanical failure of long tail shaft in the power transmission system on local fishing boats," Sakon Nakhon Rajabhat University, Sakon Nakhon, Thailand, July 24, 2015.

[4] S. Sitthipong, P. Meengam, and P. Muengjunburee, "Comparison of methods for welding repairs to prolong the lifespan of the SWING SHAFT,” Thai Welding Journal, vol. 54, pp.11-18, 2011.

[5] S. Sitthipong, P. Muengjunburee, C. Dectvayukul, and N. Totarat, "Fatigue life assessment of weld surfacing of AISI 4340," IIW congress, Bangkok, Thailand, pp. 25-26, February 2010.

[6] G. Magudeesawaran, V. Balasubramanian, and R. Madhusudhan, "Effect of welding processes and consumables on high cycle fatigue life of high strength, quenched and tempered steel joints," Journal of Materials Processing Technology, vol. 29, pp. 1821-1827, 2008.

[7] S. Bagherifard, R. Fernandez-Pariente, and M. Ghelichi, "Effect of severe shot peening on microstructure and fatigue strength of cast iron,” International Journal of Fatigue, vol. 65, pp. 64-70, 2014.

[8] G. Magudeesawaran, V. Balasubramanian, and R. Madhusudhan "Effect of welding processes and consumables on high cycle fatigue life of high strength, quenched and tempered steel joints," Journal of Materials Processing Technology, vol. 29, pp. 1821-1827, 2008.

[9] N. Tareelap, K. Sriraksasin, N. Srisukhumbowornchai, S. Thuanboon and C. Nitipanyawong, "Prevention of dealloying in manganese aluminium bronze propeller,” Part II” KKU Engineering Journal, vol. 41, pp. 83-90, 2014.

[10] E. Turan, T. Kocal and K. Unlugencoglu, "Welding technologies in shipbuilding industry,” Journal of science and technology, vol. 1, pp. 24-30, 2011.

[11] J. E. Shigley, “Mechanical Engineering Design Matrix,” New York: McGraw-Hill Book, 1986. 
[12] C. R. A. Schneider and S. J. Maddox, "Best practice guide on statistical analysis of fatigue data," International Institute of Welding, U.K., 2003.

[13] O. H. Basquin, "The exponential law of endurance tests," American Society for Testing and Materials, pp. 625-630, 1910.

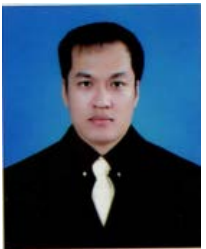

Siv a Sitthipong earned a bachelor degree in mechanical engineering from Prince of Songkla University, Thailand and a master degree in material engineering from Prince of Songkla Universit, Thailand In 2014, he furthered his $\mathrm{PhD}$ at Marine and Coastal Resource Institute (Macorin), Prince of Songkla University, Thailand. He is currently a professional engineer,energy auditor and managing director at mechmat engineering company limited, Thailand. His current research interests are failure analysis, predictive maintenance, welding repair process and marine engineering.

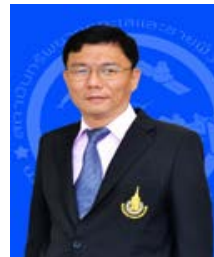

Prawit Towatana got a bachelor degree in soil science from Kasetsart University, Thailand, a master degree in mineralogy from Washington State University, USA. In 1990, he earned the PhD in geochemistry from University of Idaho, USA. He is currently an associate professor at MACORIN, Prince of Songkla University, Thailand.

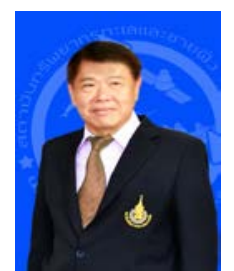

Amnuay Sitticharoenchai earned a bachelor degree in agricultural mechanization from Kasetsart University, Thailand, a master degree in agricultural engineering from UPLB, Philipines. In 1989, he got the $\mathrm{PhD}$ in machinisme agricole from L'ENSAM, France. He is currently an assistant professor at MACORIN, Prince of Songkla University, Thailand. 